\title{
Determination of Dolus and Tempus Delicti on the Crime of Hate Speech Conducted from Outside the State of Indonesia by Using Social Media Facilities
}

\author{
I Wayan Budha Yasa ${ }^{*}$ \\ ${ }^{1}$ Universitas Pendidikan Ganesha, Indonesia \\ *e-mail: budhayasa28@gmail.com \\ Article history: Received 15 December 2020; Accepted 31 March 2021; Available online 30 April 2021
}

\begin{abstract}
The development of information technology, media and communication at this time has changed the behavior of society and human civilization globally. In this regard, in addition to the positive benefits arising from the

\section{Keywords:}

Locus and Tempus Delicti; Hate Speech; Social Media development of information technology and so on, such as the emergence of facilities or media that can make it easier for humans to work, there are also negative impacts, such as crimes in cyberspace. One of the crimes in cyberspace in question is hate speech. These actions can be classified into criminal acts, because these actions will have an impact on society in general. Moreover, this action was carried out from outside the State of Indonesia using social media facilities, of course it would be very difficult to determine the place (locus delicti) and time (tempus delicti) to try the perpetrators of the hate speech crime. For this reason, it is necessary to know how to determine the locus and tempus delicti of the crime or crime in question.
\end{abstract}

Copyright @ Universitas Pendidikan Ganesha. All rights reserved.

\section{Introduction}

The development of information technology, media and communication at this time has changed the behavior of society and human civilization globally. The development of information technology, media and communication also causes world relations to become unlimited, causing significant social, economic and cultural changes to take place quickly. The development of information technology, media, and communication is also likened to a doubleedged knife, this is because in addition to providing benefits or contributing to the improvement of welfare, progress and human civilization, the development of information technology, media, and communication can also be used as a means of taking action. against the law which of course can harm other people individually or in groups.

One proof of the rapid development of information, media and communication technology is the creation of social media as a tool to disseminate information, communicate and so on very effectively and efficiently. From this, of course, it can make it easier for humans to carry out their lives. But besides the positive benefits they have, these technological developments also have a negative impact on human life. The negative impact caused is none other than the result of the actions of certain parties who take advantage of these technological developments as a means to benefit themselves and their groups. In addition, with the rapid development of technology and the birth of various means to facilitate mankind in communicating, disseminating information, 
and so on, it is also used as a means to commit crimes and of course violate the law and can harm others as well.

In this regard, the real world of law has long since broadened the interpretation of its principles and norms when facing intangible material problems, such as the case of electricity theft as a criminal act. Thus, the law should be able to cover all forms of action that can create imbalance or injustice in society, including actions that are carried out on matters related to information technology or cyberspace. In addition, increasing the power of law in covering technological developments also aims to guarantee legal certainty to the public and to become one of the supports in the development and utilization of information technology in the future.

In connection with the title of the author, which is related to hate speech, it is necessary to know what hate speech is and social media as a means used to commit these criminal acts. Newton Lee says there is a fine line between free speech and hate speech. Free speech encourages debate whereas hate speech incites violence. Newton Lee also distinguished between free speech and hate speech. Freedom of speech can lead to debate whereas hate speech can ignite violence. Hate speech in question may result in enmity between certain parties and can lead to violence. Hate speech can occur anywhere and anytime, especially actions in this technological age. Social media is an easy tool for hate speech. Social Media or what is called New Media is a medium that offers digitization, convergence, interaction, and development of networks related to message creation and message delivery. Its ability to offer interactivity allows users of new media to have a choice of what information to consume, as well as control the output of the resulting information and make the desired choices. By looking at the capabilities of social media, when hate speech occurs on social media, it will certainly be difficult for us to know where and when the action was carried out, especially if it was carried out outside the territorial boundaries of a country's law. Thus, it becomes a challenge in overcoming acts of hate speech whose tendency can lead to polemics in society. Based on the background description above, the main problems to be analyzed are: How to determine the locus and tempus delicti of hate speech crimes committed outside the State of Indonesia using social media facilities?

\section{Result and Discussion}

\section{Locus Delicti}

Locus delicti, in terms of the term, is the enactment of criminal law as seen from the point of view of the location of the crime. Locus delicti needs to be known to determine whether Indonesian criminal law applies to the criminal act or not (this relates to Articles 2-8 of the Criminal Code and determines the relative competence of the prosecutor's office and which court or prosecutor's office or court is authorized to handle a criminal case (Article 84 (1) The Criminal Procedure Code which contains the basic principles of relative competence, nam ely the District Court is authorized to adjudicate all criminal cases committed within its jurisdiction) and as one of the absolute requirements for the validity of the indictment There are four theories to determine the location of the criminal incident or locus delicti, namely :

1) The theory of material action (leer van de lichamelijkedaad) is a theory based on physical actions, which is why this theory emphasizes that what is considered the place of the crime locus delicti is the place where the act is committed;

2) The theory of tools (leer van het instrument) is a theory based on the functioning of a tool used in a criminal act, so this theory confirms that what is considered the place where the crime occurs is the place where the tools used in the criminal act react;

3) Result theory (leer van het gevolg) is a theory based on the consequences of a crime. According to this theory, what is considered a locus delicti is a place where the consequences of the crime arise; and 
4) The theory of multiple places (leer van de lichamelijke daad) is a theory which confirms that what is considered the place of the crime is the places where the act physically takes place, the place where the tools used react, and the place where the consequences of the crime occur.

In determining the application of criminal law based on place, of course, one must also consider the scope of the application of the national criminal law according to the place where it occurs. Actions (national law jurisdiction), when viewed from the point of view of the state there are 2 (two) opinions, namely:

1) Criminal law legislation applies to all criminal acts that occur in the territory of the state, whether committed by their own citizens or by other people (territorial principle).

2) Criminal law legislation applies to all criminal acts committed by citizens, anywhere, also if the criminal act is committed outside the territory of the state (personal principle or active national principle).

In this section, we will be able to see the application of criminal law according to the space of the place and it also relates to the person or subject. From this there are also principles of criminal law according to place, the principles in question are as follows.

1) Territorial Principle, this principle is regulated in the Criminal Code (KUHP), namely in article 2 of the Criminal Code which states "Criminal provisions in Indonesian legislation are applied to anyone who commits a crime in Indonesia". This article clearly states the territorial principle and this provision naturally applies to a sovereign state. The territorial principle focuses more on the occurrence of criminal acts within the territory of the state regardless of who the perpetrators are, citizens or foreigners. Whereas in the personal or national principle, actively focus on the person who commits the criminal act, it does not matter where the crime occurred. The territorial principle which is currently followed by many countries in the world, including Indonesia. This is natural because everyone who is in the territory of a country must comply with and obey the laws of the State where the person concerned is located.

2) Personal principle, this principle is also called the active national principle. This principle may not be fully used against citizens who are in the territory of another country whose position is equally sovereign. If a foreign citizen residing in the territory of a country has committed a criminal act and is not being tried according to the law of that country, it means that it is contrary to the sovereignty of that country. Article 5 of the Indonesian Criminal Code applies to Indonesian citizens outside Indonesia who have committed certain criminal acts, crimes against state security, the dignity of the head of state, incitement, and so on.

3) The principle of protection, although the personal principle is no longer fully utilized, there are other principles that allow the enactment of the national criminal law against criminal acts that occur outside the territory of the state. (Article 4 of the Criminal Code (after being amended and added based on Law Number 4 of 1976)).

4) Universal principles, the entry into force of Articles 2-5 and 8 of the Criminal Code are limited by exceptions in international law. Whereas the principle of protecting international interests (universal principle) is based on the premise that every country in the world is obliged to participate in implementing the world legal system (international law). (Articles $2-5,7$, and 8 of the Criminal Code).

The locus delicti in question is clearly not contained in the Criminal Code, but has something to do with the articles in the Criminal Code. The objectives of the locus delicti are as follows.

1) Determine whether Indonesian criminal law continues to apply to the criminal act or not (Articles 2-8 of the Criminal Code);

2) Determine which prosecutors and courts have the authority to administer cases (relative competence);

3) One of the absolute conditions for the validity of an indictment. 


\section{Tempus Delicti}

Tempus delicti, namely the time when the crime occurred. The timing of a criminal act (tempus delicti) always corresponds to the place of the crime (locus delicti), meaning that where and when the elements of a criminal act have been completed, that perfect moment is the time of the crime. By following descriptions of the teachings of the place of the crime, the timing of the crime follows one of the teachings or theories contained in the locus delicti. The teachings of tempus delicti are known in terms of determining the following matters.

1) Whether an act at that time has been prohibited and threatened with punishment (Article 1 paragraph 1 of the Criminal Code);

2) If there is a change in legislation, the provisions of the applied court, new or old laws (Article 1 paragraph 2 of the Criminal Code);

3) Whether the defendant can be held responsible or not at the time of committing a crime (Article 44 of the Criminal Code);

4) Was the defendant 12 years old at the time of committing the crime (in connection with the application of the provisions of Law No. 11 of 2012 concerning the Juvenile Criminal Justice System);

5) The limit for filing a complaint starts when the person entitled to complain becomes aware of a crime (Article 74 of the Criminal Code), the time limit for withdrawing the complaint (Article 75 KUHP); and

6) Prosecution expires (Article 79 KUHP), and being caught in the act is the arrest of a person while committing a criminal act and so on (Article 1 point 19 of the Criminal Procedure Code).

\section{Hate Speech on Social Media}

In connection with the criminal act of hate speech committed from outside the State of Indonesia by using social media, of course it must be known what the actual crime of hate speech itself is, especially if such acts are carried out outside the State of Indonesia by using social media.

Hate speech is an act of communication carried out by an individual or group in the form of provocation, incitement, or insult to other individuals or groups in various aspects such as race, color, ethnicity, gender, disability, sexual orientation, nationality, religion, and etc. In a legal sense, hate speech is prohibited speech, behavior, writing or performance because it can trigger acts of violence and prejudice either from the perpetrator, the statement, or the victim of the action. Sites that use or employ hate speech are called hate sites. Most of these sites use internet forums and news to reinforce certain points of view. Critics argue that the term hate speech is a modern example of the novel Newspeak, where hate speech is used to secretly criticize a social policy that is badly implemented and rushed as if it seemed politically correct. According to R. Susilo, what is meant by insulting is attacking the honor and good name of someone, who is affected by hate speech usually feels ashamed. According to him, there are several kinds of insults to an individual, namely: verbally insulting, insulting by letter / written, slandering, light insulting, complaining in slanderous ways, and accusations of slander. Here are some definitions of hate speech related to social media.

1) The Facebook platform, hate speech is defined as direct attacks on people based on things called protected characteristics, namely race, ethnicity, nationality, religion, sexual orientation, gender, gender or gender identity as well as disability or serious illness. This Facebook platform protects against age-based attacks when age is paired with other protected characteristics and also provides certain protections for immigration status. The Facebook platform defines attacks as harsh or inhuman speech, dangerous stereotypes, derogatory statements, or calls for exclusion or exile. 
2) Youtube, hate speech is defined as calls for violence or hatred against individuals or groups based on one of the attributes such as age, caste, disability, ethnicity, gender identity and expression, nationality, race, immigration status, religion, gender, sexual orientation, victim major violent events and their families, as well as veteran status.

3) Twitter: "Hateful conduct: You may not promote violence against or directly attack or threaten other people on the basis of race, ethnicity, national origin, sexual orientation, gender, gender identity, religious affliation, age, disability, or serious disease."

In connection with the criminal act of hate speech carried out outside the State of Indonesia by using social media facilities, it is necessary to know the legal basis applicable in the State of Indonesia which is of course related to this problem. The legal basis for this is Law Number 11 of 2008 concerning Electronic Information and Transactions as amended by Law Number 19 of 2016 concerning Amendments to Law Number 11 of 2008 concerning Electronic Information and Transactions. In addition, there are several aspects / attributes mentioned in the definition of hate speech according to several social media above which are also contained in the Circular of the Chief of the National Police of the Republic of Indonesia Number SE / 6/2015 of 2015 concerning Handling Hate Speech. In this circular, it is explained that hate speech can be in the form of those regulated in the Criminal Code (KUHP) and outside the Criminal Code, which are in the form of insult, defamation, defamation, unpleasant acts, provocation, incitement, spreading false news and All of the above actions have the purpose or could have an impact on acts of discrimination, violence, loss of life, and / or social conflict. Furthermore, that the hate speech as referred to above aims to incite and incite hatred against individuals and / or community groups in various communities which are differentiated from aspects of ethnicity, religion, religious sect, belief / belief, race, intergroup, skin color, ethnicity, gender, people with disabilities (disabilities), and sexual orientation. Essentially an insult, defamation is an act of attacking someone's honor or good name, so that that person's good name is tainted or damaged. In determining the existence of an insult or defamation, content and context are very important parts to understand. An intrinsically defiled or damaged one's reputation can only be assessed by that person. In other words, it is the victim who can judge subjectively what content or parts of information or electronic documents he feels have offended his honor or reputation.

\section{Conclusion}

Based on the description of the above discussion related to how to determine the locus and timpus delicti of hate speech crimes committed outside the State of Indonesia using social media facilities, the following conclusions can be drawn. The way to determine the locus delicti of hate speech crimes committed outside the State of Indonesia using social media facilities is to know where the crime was committed, where the tool used to commit the crime reacted, and where the place that experienced the consequences of the criminal act was committed. done. In connection with hate speech crimes committed from outside the State of Indonesia and using social media as the means, it is necessary to pay attention to whether the tools used react in the State of Indonesia and the consequences it causes. Thus, this has something to do with the personal principle, whereby anyone who commits a crime from abroad will be prosecuted in the State of Indonesia using the positive law in force in Indonesia (KUHP) and the perpetrator of the crime can be extradited from the country where he lives. then submitted to the State of Indonesia to be tried. This means that perpetrators of hate speech crimes will be tried in the State of Indonesia with the legal system in force in the country of Indonesia, provided that actions are considered hate speech or all the elements in the applicable laws and regulations in the State of Indonesia (Law Number 11 Of 2008 concerning Electronic Information and Transactions as amended by Law Number 19 of 2016 concerning Amendments to Law Number 11 of 2008 concerning Electronic Information and Transactions). The use of the ITE Law is based on actions committed with social media (information technology) in cyberspace. 
The way to determine the tempus delicti for hate speech crimes committed outside the State of Indonesia by using social media means is to find out whether the act is prohibited, what provisions are used (old rules or new rules), whether the perpetrator can be held responsible for the wrongdoing. whether the perpetrator is 12 (twelve) years old (relating to child protection), whether the deadline for filing a criminal report is in accordance with the applicable provisions, and in accordance with the expiration determination. In connection with hate speech crimes committed outside the State of Indonesia by using social media facilities, the method of determining the tempus delicti must still pay attention to the locus delicti and the underlying legal rules, for example if in dolus delicti it is determined that the crime in question is in the State of Indonesia, then the rules the underlying law is of course the positive law that applies in the State of Indonesia. The law in question is the Criminal Code and Law Number 11 of 2008 concerning Electronic Information and Transactions as amended by Law Number 19 of 2016 concerning Amendments to Law Number 11 of 2008 concerning Electronic Information and Transactions, with this legal provision, it will be known whether the perpetrator of the hate speech crime in question can be tried or not.

Based on the description of the conclusions above, the advice I can give as the compiler of this paper is to ask the legal structure or in this case law-making officials and law enforcement officials to provide clear legal certainty, so as to provide justice for victims of hate speech crimes, in particular. carried out outside the State of Indonesia using social media facilities, both Indonesian citizens and foreign nationals. In addition, it is very necessary to form a more direct or detailed law regarding crimes that can be carried out through social media (information technology), because these crimes are very dangerous to many people and one of them is related to hate speech crimes. Moreover, the crimes in question are committed between countries, which will certainly cause conflict or disputes between citizens of the country in question.

\section{Reference}

Facebook

Community Standards.

(2020).

Available

in https://web.facebook.com/communitystandards/objectionable_content?_rdc=1\&_rdr.

Irawan. (2018). Hate Speech di Indonesia: Bahaya dan Solusi. Jurnal Dakwah dan Pengembangan Sosial Kemanusiaan.

Kitab Undang-Undang Hukum Pidana (KUHP).

Kurnia, A. J. (2018). Jerat Hukum Penyebar Ujaran Kebebncian di Youtube. Available in https://www.hukumonline.com/klinik/detail/ulasan/lt584a704d611dc/jerat-hukumpenyebar-ujaran-kebencian-di-youtube.

Noname. (2010). Modul Azas-Azas Hukum Pidana Untuk Diklat Pendahuluan Pendidikan dan Pelatihan Pembentukan Jaksa (PPPJ) Tahun 2010. Jakarta: Pusat Pendidikan dan Pelatihan Kejaksaan Republik Indonesia.

Philbert Audric Diego, P. A. \& Tawang, D. A. (2020). Analisis Limitasi Locus dan Tempus Delicti Dalam Delik Penipuan yang Terjadi di Luar Negeri (Studi Putusan Mahkamah Agung Nomor 58/PK/PID/2018). Jurnal Hukum Adigama.

Sofyan, A. \& Azisa, N. (2016). Hukum Pidana. Makasar: Pustaka Pena Press.

Surat Edaran Kepala Kepolisian Negara Republik Indonesia Nomor SE/6/2015 Tahun 2015 tentang Penanganan Ujaran Kebencian (Hate Speech).

Twitter Rules and Policies. Hateful Conduct Policy. https://help.twitter.com/en/rules-andpolicies/hateful-conduct-policy.

Undang-Undang Nomor 11 Tahun 2008 tentang Informasi dan Transaksi Elektronik sebagaimana telah diubah dengan Undang-Undang Nomor 19 Tahun 2016 tentang Perubahan Atas Undang-Undang Nomor 11 Tahun 2008 tentang Informasi dan Transaksi Elektronik.

Watie, E. D. S. (2011). Komunikasi dan Media Sosial. The Messenger, 3(1). 
I Wayan Budha Yasa/Determination of Dolus and Tempus Delicti on the Crime of Hate Speech Conducted from Outside the State of Indonesia by Using Social Media Facilities

Wikipedia Free Encyclopedia. Hate speech. Available in https://id.wikipedia.org/wiki/Ucapan_kebencian.

$\begin{array}{lllll}\text { Youtube help. Hate } & \text { Speech } & \text { Policy. Available }\end{array}$ https://support.google.com/youtube/answer/2801939. 